\title{
Asthmatic Versus Non-Allergic Children in Relation to The Presence of Cow Milk Allergy
}

Hadeel I. Enany*1, M. H. M. Ebrahim ${ }^{1}$, E. M. Rasheed ${ }^{1}$, Eman M. Elbehedy ${ }^{2}$, Shereen A. Baioumy ${ }^{2}$

Department of ${ }^{1}$ Pediatric and ${ }^{2}$ Microbiology and Immunology, Faculty of medicine, Zagazig University, Egypt

*Corresponding author: Hadeel Ibrahim Enany, Mobile: (+20)01021067578, Email: hadeelibraheem2016@gmail.com

\begin{abstract}
Background: Cow's milk allergy is among the most frequent food allergies in young children and one of the risk factors of asthma.

Objective: The study aimed to assess the role of Cow's milk allergy (CMA) to induce asthma and to study the effect cow milk protein on asthmatic and non-allergic children to prevent occurrence of asthma among children.

Patients and methods: A case-control study that was carried out in Pulmonology Unit of Pediatric Department, Faculty of Medicine, Zagazig University Hospital. The patients were investigated at Medical Community and Immunology Department. The study included 154 child divided equally into two groups. Group A included patients with bronchial asthma and group B (control) included age- and sex-matched healthy individuals. Iinvestigations: complete blood picture, renal and liver function tests, skin prick test, total immunoglobulin (IgE) was done for all participants.

Results: There was high statistically significant difference between the two studied groups as regards skin pick test. There was statistically significant increase in the levels of both total and specific Ig E in allergic group compared to control group. There was high significant increase in the severity recorded in respiratory function test in allergic group compared to control group. There was non-significant difference between the two groups regarding GIT manifestation. There was high statistically significant difference between the two groups regarding skin and respiratory manifestations. Conclusion: CMA can exacerbate the symptoms in children with asthma. Therefore, it is worth considering a possible role of food allergy in asthma in young children, particularly when asthma is not adequately controlled in spite of proper routine management.
\end{abstract}

Keywords: Asthma, Non-allergic children, Cow milk allergy.

\section{INTRODUCTION}

The food allergy and asthma are the most common chronic conditions in childhood. The prevalence of asthma and allergic diseases like allergic rhinitis in childhood has shown an increasing trend in several industrialized countries since the second half of the twentieth century ${ }^{(\mathbf{1})}$. Cow's milk allergy (CMA) is defined as an adverse clinical reaction to ingested cow's milk proteins based on an immunologically mediated adverse reaction to the provoking proteins at doses which are tolerated by healthy persons ${ }^{(2)}$.

A key component in the pathology is chronic inflammation and various factors such as viruses, allergens and exercise. These factors are also responsible for hyper-responsiveness, inflammation together with hyper-reactivity associated with airway obstruction. Asthma can present with symptoms such as recurrent episodes of wheezing, coughing, shortness of breath, and chest tightness. In addition to medical history, methods to establish asthma diagnosis include physical examination, evaluation of lung function, atopy, airway inflammation, bronchial hyperresponsiveness and exclusion of alternative diagnosis. In young children, the asthma diagnosis is particularly challenging due to difficulties in applying objective lung function measurements. Thus, in infants and preschool-aged children, the diagnosis is often based on medical history and symptoms ${ }^{(3)}$.
Therefore, the aim of the present study was to assess the role of cow milk (CM) to induce asthma and to study the effect of cow milk protein allergy on asthmatic and non-allergic children to prevent occurrence of asthma among children.

\section{PATIENTS AND METHODS}

A case-control study that was carried out in Pulmonology Unit of Pediatric Department, and investigated at Medical Community and Immunology Department, Zagazig University Hospital. The study included 154 participants divided into 2 groups. Group A, 77 patients with bronchial asthma and group B, 77 healthy control group.

\section{Ethical consent:}

An approval of the study was obtained from Zagazig University Academic and Ethical Committee. Every patient signed an informed written consent for acceptance of the study. This work has been carried out in accordance with the Code of Ethics of the World Medical Association (Declaration of Helsinki) for studies involving humans.

Inclusion criteria: Patients with asthma that were diagnosed on the basis of symptoms and physical examination of respiratory systems. Both males and females of age from 6 to $12 \mathrm{y}$. 


\section{Exclusion criteria:}

Patients with presence of diseases other than cow milk protein allergy that could increase the risk of asthma exacerbation and use of systemic steroid within 2 week of study.

All children underwent full history taking including (chief complaint, past medical history, pregnancy and birth history, developmental history, feeding history and family history) and general examination of the child including vital signs, weight in kilograms and height in centimeters.

\section{Laboratory investigations:}

Complete blood picture, renal function tests, liver tests profile, skin prick test, total $\mathrm{IgE}$ (serum specific IgE for cow milk proteins) and respiratory function tests were performed for all studied cases.

\section{Statistical analysis:}

Data were analyzed using IBM SPSS 23.0 for windows (SPSS Inc., Chicago, IL, USA) and NCSS 11 for windows (NCSS LCC., Kaysville, UT, USA). Quantitative data were expressed as mean \pm standard deviation (SD). Qualitative data were expressed as frequency and percentage. The following tests were done: Independent sample t- test of significance was used when comparing between two means. MannWhitney test was used when comparing two means of not normally distributed data. Chi-square $\left(\mathrm{X}^{2}\right)$ test of significance was used in order to compare proportions between two qualitative parameters. Fisher Exact test is a test of significance that was used in the place of chi square test in 2 by 2 tables, especially in cases of small samples. Probability (P-value): P-value $\leq 0.05$ was considered significant, $\mathrm{P}$-value $\leq 0.001$ was considered as highly significant and P-value $>0.05$ was considered insignificant.

\section{RESULTS}

The age ranged from 6 to 11 years in group 1 with a mean of $7.9 \pm 1.7$ years while in group 2 the mean was $8.0 \pm 1.9$ years with no statistical significant difference $(\mathrm{p}=0.924)$ between the two groups. There was no statistical significant difference between the two groups as regards gender $(\mathrm{p}=1.00)$. Additionally, there was no statistical significant difference between the two groups regarding weight and length $(\mathrm{p}=0.212 \& 0.793$ respectively) (Table 1).

There was high statistically significant difference between the two studied groups as regards skin pick test $(\mathrm{p}<0.001)$ (Table 2$)$.

There was statistically significant increase in the levels of both total and specific Ig E ( $<<0.001)$ in allergic group (group 2) compared to control group (group 1) (Table 3).

There was high significant increase in the severity recorded $(\mathrm{p}<0.001)$ in respiratory function test in allergic group (group 2) compared to control group (group 1) (Table 4).

There was no statistically significant difference between the two groups regarding GIT manifestation ( $\mathrm{p}$ $=0.292$ ). While, there was high statistically significant difference between the two groups regarding skin and respiratory manifestations $(\mathrm{p}<0.001)$ (Table 5).

There was high statistically significant difference between the two groups regarding family history of bronchial asthma $(\mathrm{p}=0.002)$. In addition, there was statistically significant difference between the two groups regarding family history of cow milk allergy $(\mathrm{p}=0.025)($ Table 6).

Table (1): Correlative demographic characteristics between the two studied groups

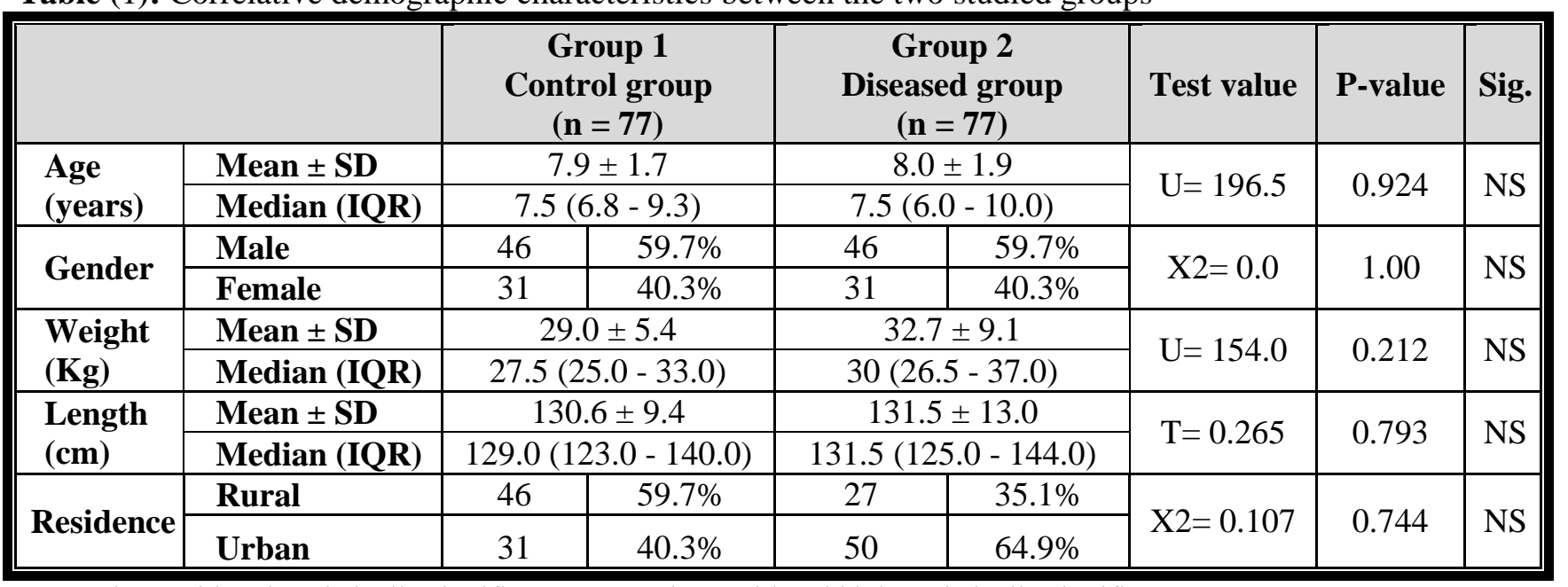

$\mathrm{p} \leq 0.05$ is considered statistically significant, $\mathrm{p} \leq 0.01$ is considered high statistically significant, $\mathrm{SD}=\mathrm{standard}$ deviation, comparison between groups done by Independent Samples Student T test, Chi-Square Test and Mann- Whitney U test 
Table (2): Correlation of skin pick test between the two studied groups

\begin{tabular}{|c|c|c|c|c|c|c|c|c|}
\hline & & \multicolumn{2}{|c|}{$\begin{array}{c}\text { Group } 1 \\
\text { Control group } \\
(\mathbf{n}=77) \\
\end{array}$} & \multicolumn{2}{|c|}{$\begin{array}{c}\text { Group } 2 \\
(n=77)\end{array}$} & \multirow[t]{2}{*}{ Test value } & \multirow[t]{2}{*}{ P-value } & \multirow[t]{2}{*}{ Sig. } \\
\hline & & $\mathbf{n}$ & $\%$ & $\mathbf{n}$ & $\%$ & & & \\
\hline \multirow{5}{*}{$\begin{array}{l}\text { Skin } \\
\text { pick } \\
\text { test }\end{array}$} & Negative & 58 & $75.3 \%$ & 0 & $0.0 \%$ & \multirow{5}{*}{$X^{2}=40.0$} & \multirow{5}{*}{$<0.001$} & \multirow{5}{*}{ HS } \\
\hline & Positive $(<3 \mathrm{~mm})$ & 19 & $24.7 \%$ & 0 & $0.0 \%$ & & & \\
\hline & Positive (3-7mm) & 0 & $0.0 \%$ & 23 & $29.9 \%$ & & & \\
\hline & Positive (7-9mm) & 0 & $0.0 \%$ & 31 & $40.3 \%$ & & & \\
\hline & Positive (> 9mm) & 0 & $0.0 \%$ & 23 & $29.9 \%$ & & & \\
\hline
\end{tabular}

$\mathrm{p} \leq 0.05$ is considered statistically significant, $\mathrm{p} \leq 0.01$ is considered high statistically significant, $\mathrm{SD}=$ standard deviation, comparison between groups done by Pearson Chi Square test and Student $\mathrm{T}$ test

Table (3): Correlation of total IgE and specific IgE between the two studied groups

\begin{tabular}{|c|c|c|c|c|c|c|}
\hline & & $\begin{array}{c}\text { Group } 1 \\
\text { Control group } \\
(\mathbf{n}=77) \\
\end{array}$ & $\begin{array}{c}\text { Group } 2 \\
\text { Diseased group } \\
(\mathbf{n}=77) \\
\end{array}$ & Test value & P-value & Sig. \\
\hline \multirow[b]{2}{*}{ Total Ig E } & Mean \pm SD & $13.9 \pm 14.3$ & $302.8 \pm 103.9$ & \multirow[b]{2}{*}{$\mathrm{U}=0.0$} & \multirow[b]{2}{*}{$<0.001$} & \multirow[b]{2}{*}{ HS } \\
\hline & Median (IQR) & $8.8(3.8-21.0)$ & $302.0(206.0-380.0)$ & & & \\
\hline \multirow{2}{*}{ Specific Ig E } & Mean \pm SD & $0.27 \pm 0.33$ & $43.93 \pm 59.54$ & \multirow{2}{*}{$\mathrm{U}=0.0$} & \multirow{2}{*}{$<0.001$} & \multirow[b]{2}{*}{ HS } \\
\hline & Median (IQR) & $0.2(.00-0.44)$ & $29.5(20.50-42.50)$ & & & \\
\hline
\end{tabular}

$\mathrm{p} \leq 0.05$ is considered statistically significant, $\mathrm{p} \leq 0.01$ is considered high statistically significant, $\mathrm{SD}=$ standard deviation, comparison between groups done by Mann Whitney U test

Table (4): Correlation of respiratory function test recorded between the two studied groups

\begin{tabular}{|c|c|c|c|c|c|c|c|c|}
\hline & & \multicolumn{2}{|c|}{$\begin{array}{c}\text { Group } 1 \\
\text { Control group } \\
(\mathbf{n}=77)\end{array}$} & \multicolumn{2}{|c|}{$\begin{array}{c}\text { Group } 2 \\
\text { Diseased group } \\
(\mathbf{n}=77)\end{array}$} & \multirow[t]{2}{*}{ Test value } & \multirow[t]{2}{*}{ P-value } & \multirow[t]{2}{*}{ Sig. } \\
\hline & & $\mathbf{n}$ & $\%$ & $\mathbf{n}$ & $\%$ & & & \\
\hline \multirow{4}{*}{$\begin{array}{l}\text { Severity of } \\
\text { Respiratory } \\
\text { function test }\end{array}$} & Normal & 77 & $100.0 \%$ & 0 & $0.0 \%$ & \multirow{4}{*}{$X^{2}=40.0$} & \multirow{4}{*}{$<0.001$} & \multirow{4}{*}{ HS } \\
\hline & Mild & 0 & $0.0 \%$ & 15 & $19.5 \%$ & & & \\
\hline & Moderate & 0 & $0.0 \%$ & 39 & $50.6 \%$ & & & \\
\hline & Severe & 0 & $0.0 \%$ & 23 & $29.9 \%$ & & & \\
\hline
\end{tabular}

$\mathrm{p} \leq 0.05$ is considered statistically significant, $\mathrm{p} \leq 0.01$ is considered high statistically significant, $\quad \mathrm{SD}=$ standard deviation, comparison between groups done by Chi-Square Test

Table (5): Correlation between the two groups regarding clinical manifestation

\begin{tabular}{|c|c|c|c|c|c|c|c|c|}
\hline & & \multicolumn{2}{|c|}{$\begin{array}{c}\text { Group } 1 \\
\text { Control group } \\
(\mathbf{n}=77) \\
\end{array}$} & \multicolumn{2}{|c|}{$\begin{array}{c}\text { Group } 2 \\
\text { Diseased group } \\
(\mathbf{n}=77) \\
\end{array}$} & \multirow[t]{2}{*}{ Test value } & \multirow[t]{2}{*}{ P-value } & \multirow[t]{2}{*}{ Sig. } \\
\hline & & $\mathbf{n}$ & $\%$ & $\mathbf{n}$ & $\%$ & & & \\
\hline \multirow{2}{*}{ GIT symptoms } & Absent & 73 & $94.8 \%$ & 65 & $84.4 \%$ & \multirow{2}{*}{$X^{2}=1.11$} & \multirow{2}{*}{0.292} & \multirow{2}{*}{ NS } \\
\hline & present & 4 & $5.2 \%$ & 12 & $15.6 \%$ & & & \\
\hline \multirow{2}{*}{ Skin symptoms } & Absent & 77 & $100.0 \%$ & 19 & $24.7 \%$ & \multirow{2}{*}{$X^{2}=24.0$} & \multirow{2}{*}{$<0.001$} & \multirow{2}{*}{ HS } \\
\hline & present & 0 & $0.0 \%$ & 58 & $75.3 \%$ & & & \\
\hline \multirow{2}{*}{$\begin{array}{l}\text { Respiratory } \\
\text { symptoms }\end{array}$} & Absent & 77 & $100.0 \%$ & 0 & $0.0 \%$ & \multirow{2}{*}{$X^{2}=40.0$} & \multirow{2}{*}{$<0.001$} & \multirow{2}{*}{ HS } \\
\hline & present & 0 & $0.0 \%$ & 77 & $100.0 \%$ & & & \\
\hline
\end{tabular}

$\mathrm{p} \leq 0.05$ is considered statistically significant, $\mathrm{p} \leq 0.01$ is considered high statistically significant, $\quad \mathrm{SD}=$ standard deviation, comparison between groups done by Chi-Square Test 
Table (6): Correlation of family history between the two studied groups

\begin{tabular}{|c|c|c|c|c|c|c|c|c|}
\hline & & \multicolumn{2}{|c|}{$\begin{array}{c}\text { Group } 1 \\
\text { Control group } \\
(\mathbf{n}=77) \\
\end{array}$} & \multicolumn{2}{|c|}{$\begin{array}{c}\text { Group } 2 \\
\text { Diseased group } \\
(\mathrm{n}=77) \\
\end{array}$} & \multirow[t]{2}{*}{ Test value } & \multirow[t]{2}{*}{ P-value } & \multirow[t]{2}{*}{ Sig. } \\
\hline & & n & $\%$ & n & $\%$ & & & \\
\hline \multirow{2}{*}{$\begin{array}{l}\text { Family history of } \\
\text { bronchial asthma }\end{array}$} & Negative & 58 & $75.3 \%$ & 23 & $29.9 \%$ & \multirow{2}{*}{$X^{2}=8.12$} & \multirow{2}{*}{0.002} & \multirow{2}{*}{$\mathrm{HS}$} \\
\hline & Positive & 19 & $24.7 \%$ & 54 & $70.1 \%$ & & & \\
\hline \multirow{2}{*}{$\begin{array}{l}\text { Family history of } \\
\text { cow milk allergy }\end{array}$} & Negative & 58 & $75.3 \%$ & 31 & $40.3 \%$ & \multirow{2}{*}{$X^{2}=5.01$} & \multirow{2}{*}{0.025} & \multirow{2}{*}{ S } \\
\hline & Positive & 19 & $24.7 \%$ & 46 & $59.7 \%$ & & & \\
\hline
\end{tabular}

$\mathrm{p} \leq 0.05$ is considered statistically significant, $\mathrm{p} \leq 0.01$ is considered high statistically significant, $\quad \mathrm{SD}=$ standard deviation, comparison between groups done by Chi-Square Test

\section{DISCUSSION}

Analysis of our findings revealed that the age ranged from 6 to 11 years in group 1 with mean of 7.9 \pm 1.7 years while in group 2 the mean was $8.0 \pm 1.9$ years with no statistical significant difference $(\mathrm{p}=0.924)$ between the two groups. There was no statistical significant difference between the two groups as regards gender $(\mathrm{p}=1.00)$. There was no statistical significant difference between the two groups regarding weight and height ( $\mathrm{p}=0.212 \& 0.793$ respectively). In comparison with the study of Ito et al. ${ }^{(4)}$ in which eighty-three children with a suspected IgE-mediated cow's milk allergy (CMA) were enrolled in the study. The patients (male/female ratio, 55/28) and ranged in age from 0.8 to 15.8 years (median: 3.5 years).

In the current study, as regards skin pick test among the two studied groups, it was significantly positive in patient group than control group $(\mathrm{p}<0.001)$. Misırlıog and Cengizlier ${ }^{(5)}$ reported that atopy-related tests revealed a high total $\mathrm{IgE}$ median level at 524.3 $\mathrm{IU} / \mathrm{ml}$, which is higher than our study which was 302 . The specific IgE (AlaTOP and food panel) level was determined in 625 patients of which 325 (48\%) were positive. 1902 of the 3025 patients had received a skin pick test with $1146(60.3 \%)$ found to be atopic and 756 $(39.7 \%)$ non-atopic. 149 (13\%) of the atopic patients had mono-allergen sensitivity ${ }^{(5)}$.

In the current study, respiratory function test was recorded among the two studied groups. There was high significant increase in the severity recorded ( $<$ < 0.001 ) in respiratory function test in allergic group (group 2) compared to control group (group 1). Koren et al. ${ }^{(6)}$ reported that fifty non-asthmatic children (26 assigned to the cow's milk group and 24 to the soy substitute group), and 46 asthmatic children (22 in the cow's milk group and 24 in the soy substitute group) were enrolled. Age, gender, and body mass index Zscore were comparable between the two groups. No changes in symptoms, spirometry, FeNO, or oxygen saturation measurements were observed following challenge in any of the participants in both groups, at any time point compared to baseline.

In the present study, the manifestations recorded among the two studied groups reveled that there was no statistically significant difference between the two groups regarding GIT manifestation $(\mathrm{p}=0.292)$. There was a high statistically significant difference between the two groups regarding skin and respiratory manifestations ( $\mathrm{p}<0.001)$. Schroeder et al. ${ }^{(7)}$ studied a family-based food allergy cohort of 567 children. They found that patients with allergy to cow's milk, egg, peanut, and nuts developed more frequently and earlier asthma than children without food allergy. Priftis et al. ${ }^{(8)}$ conducted a case-control study in 69 children with allergy to egg and/or fish in the first 3 years of life. They reported that children with food allergy in infancy were at increased risk for wheezing and bronchial hyper reactivity (BHR) during school age. Asthma symptoms were reported more frequently in the study group than in the control group, which enrolled children sensitized and non-sensitized to aeroallergens.

In the current study, as regards distribution of family history among the two studied groups, there was a high statistically significant difference between the two groups regarding family history of bronchial asthma $(\mathrm{p}=0.002)$. Also, there was statistically significant difference between the two groups regarding family history of cow milk allergy $(\mathrm{p}=0.025)$. Sheikh et al. ${ }^{(9)}$ conducted study on a sample included 395 children, ages 2-17 years [median 6], and 61\% were males. Median age in years at diagnosis was 1.5 and duration of symptoms in years was 3. Family history of asthma was reported in 285 (72\%) children. Majority of children had a diagnosis of either mild persistent asthma $(\mathrm{n}=101,26 \%)$ or moderate persistent asthma $(\mathrm{n}=265$, $67 \%$ ). Family history of asthma (parents or siblings) was documented in 285 (72\%). There was no significant difference in demographics among children with or without family history of asthma. Family history of asthma was not a significant covariate in asthma improvement over time.

\section{CONCLUSION}

Our study showed that CMA can exacerbate the symptoms in children with asthma. Therefore, it is worth considering a possible role of food allergy in asthma in young children, particularly when asthma is not adequately controlled in spite of proper routine management. Although SPT seemed to be more reliable than sIgE testing, both had suboptimal reliability. A 
definite decision should depend on performing a titrated oral challenge test.

\section{Financial support and sponsorship: Nil.}

\section{Conflict of Interest: Nil.}

\section{REFERENCES}

1. Jung Y, Seo J, Kim H et al. (2015): The relationship between asthma and bronchiolitis is modified by TLR4, CD14, and IL-13 polymorphisms. Pediatr Pulmonol., 50: 8-16.

2. Fiocchi A, Brozek J, Schünemann H et al. (2010): World Allergy Organization (WAO) Special Committee on Food Allergy. World Allergy Organization (WAO). Diagnosis and Rationale for Action against Cow's Milk Allergy (DRACMA) Guidelines. Pediatr Allergy Immunol., 21: 1-125.

3. Spycher B, Silverman M, Kuehni C (2010): Phenotypes of childhood asthma: are they real? Clin Exp Allergy, 40: 1130-114.
4. Ito K, Futamura M, Movérare $\mathbf{R}$ et al. (2012): The usefulness of casein-specific IgE and IgG4 antibodies in cow's milk allergic children. Clin Mol Allergy, 10: 1-4.

5. Misırlog D, Cengizlier R (2007): Skin prick test results of child patients diagnosed as bronchial asthma. Allergol et Immunopathol., 35 (1): 21-4.

6. Koren Y, Armoni D, Gut G et al. (2020): Respiratory effects of acute milk consumption among asthmatic and non-asthmatic children: a randomized controlled study. BMC Pediatrics, 20: 433-440.

7. Schroeder A, Kumar R, Pongracic J et al. (2009): Food allergy is associated with an increased risk of asthma. Clin Exp Allergy, 39 (2): 261-70.

8. Priftis K, Mermiri D, Papadopoulou A et al. (2008): Asthma symptoms and bronchial reactivity in school children sensitized to food allergens in infancy. $\mathbf{J}$ Asthma, 45 (7): 590-5.

9. Sheikh S, Judy P, Ann S et al. (2018): Impact of genetic factors (family history of asthma) on long-term asthma control in children. Chest, 154 (4): 806-809. 